\title{
EVALUATION OF ANTIDIABETIC AND ANTICHOLESTEROL PROPERTIES OF BISCUIT PRODUCT WITH MANGROVE FRUIT FLOUR (MFF) SUBSTITUTION
}

\author{
Jariyah $^{1^{*}}$, Endang Yektiningsih ${ }^{2}$, Ulya Sarofa ${ }^{1}$ \\ ${ }^{I}$ Department of Food Technology, Faculty of Engineering, University of Pembangunan Nasional "Veteran" \\ Jawa Timur, Raya Rungkut Madya, Gunung Anyar, Surabaya 60294, East Java, Indonesia \\ ${ }^{2}$ Department of Agribusiness, Faculty of Agriculture, University of Pembangunan Nasional "Veteran” Jawa \\ Timur, Raya Rungkut Madya, Gunung Anyar, Surabaya 60294, East Java, Indonesia
}

*jariyah.tp@upnjatim.ac.id

https://doi.org/10.34302/2019.11.4.13

Article history:

Received:

15 January 2019

Accepted:

29 September 2019

Keywords:

Antidiabetic;

Anticholesterol;

Biscuit;

Bruguiera gymnorhiza;

Sonneratia caseolaris.

\begin{abstract}
These fruits contain bioactive compounds and dietary fibers which is very potential for substitution to biscuit products. This study evaluated the antidiabetic and anticholesterol properties in the produced biscuits that were substituted with mangrove fruit flour (Pedada and Lindur fruits). This study used split plot design consisted of 2 factors. The first factor was divided into 5 groups (positive control group, negative control group, biscuit control group, Pedada biscuit group, and Lindur biscuit group), each group consisted of 4 rats and the second factor was blood taking time consisted of 5 time intervals ( $0,1,2,3$ and 4 weeks). The study parameters were rats' blood glucose, body weight, short chain fatty acids (SCFA), and lipid profiles. This study obtained that biscuits produced using mangrove fruit flour had antidiabetic properties since it could decrease rats' blood glucose and increased of body weight for 4 weeks. The biscuits feeding had no significant effect on acetic acid and butyric acid, but had significant effect on propionic acid level. Anticholesterol properties indicated that the biscuits could decrease of total cholesterol, low density, lipoprotein (LDL), triglyceride, and could increase of high density lipoprotein (HDL).
\end{abstract}

\section{Introduction}

This study is a continuation of previous study about physicochemical and organoleptical properties of biscuits that was subtituted with mangrove fruit flour (MFF). There were two types of mangrove fruit used as flour in this biscuit ingredients. The first type of mangrove fruit belonged to Pedada (Sonneratia caseolaris) then was called as pedada fruit flour (PFF) and the second type belonged to Lindur (Bruguiera gymnorizha) then was called as Lindur Fruit Flour (LFF).

The biscuit formulation was added with emulsifier Sodium Stearoyl Lactylate (SSL)
$0.5 \%$. The results of this study showed that biscuit preferred by the panelist was with substitution 20\% of PFF (biscuit PFF) and 20\% of LFF (biscuit LFF). The previous results showed that PFF and LFF contains dietary fibers and bioctive compounds, such as flavonoid, phenol, tannin (Jariyah et al., 2015), vitamin C, and minerals (Jariyah et al., 2014). Those compounds are good for health and can be used for substitution in biscuit products.

In order to find the functional properties of biscuit PFF and LFF, the antidiabetic and anticholesterol properties were evaluated to produce diabetic-friendly biscuit for diabetic 
patients. The results of study by Jariyah et al. (2016) showed that biscuit with substitution $20 \%$ of PFF and $0.5 \%$ lecithin had effect to lower blood glucose level $7.63 \mathrm{mg} / \mathrm{dL}$ during 2 hours. Harijono et al. (2013) reported that biscuit contained of alginat had effect to lower blood glucose level 9.41\%. Muhtadi et al. (2015) reported that Citrus sinensis also had antidiabetic and antihypercholesterolemic effect.

Besides diabetes, cardiovascular disease is the main cause of human mortality in developing countries which related to cholesterol level issues (Gaziano, 2007). Therefore, the biscuit in this study is expected to give a contribution as alternative functional food product from mangrove fruit, which can be consumed by diabetic patients and can decrease the cholesterol level.

\section{Materials and methods}

Mangrove fruits belonged to Pedada (Sonneratia caseolaris) and Lindur (Bruguiera gymnorhiza) were obtained from Wonorejo Village, Surabaya. The production of mangrove fruit flour referred to procedure from Jariyah $e t$ al. (2016). Wheat flour, margarine, Sodium Stearoyl Lactylate (SSL), eggs, sodium bicarbonate, glucose syrup, were obtained from Soponyono Market, Surabaya. The biscuits were produced in Laboratory of Food Processing Technology, Universitas Pembangunan Nasional "Veteran" Jawa Timur, Indonesia.

Male wistar rats were used to evaluate antidiabetic and anticholesterol properties. The rats were obtained from Laboratory of Food and Nutrition Study Centre, University of Gadjah Mada Yogyakarta. Twenty of rats were 2-3 months in age and $180-225 \mathrm{~g}$ in weight. This study got a license in Ethical Clearance from Brawijaya University, Malang, East Java, Indonesia.

\subsection{Procedure of Biscuit Production}

The process of biscuit production referred to the study from Jariyah et al. (2016) with modification from Sindhuja et al. (2005) and
El-Sharnouby et al. (2012). The sugars, margarines, eggs, and glucose syrup were mixed and added by SSL $0.50 \%$ until homogen. Then added with sodium bicarbonat, salts, skim milk, MFF, and continued mixing to produce dough. The next process was to produce dough sheets with diameter 3-4 cm; thickness $7.5 \mathrm{~mm}$. The dough sheets then were baked at $150^{\circ} \mathrm{C}$ for 6-10 mins and cooled for 30-45 mins. Once finished the biscuits' antidiabetic and anticholesterol properties were analyzed.

\subsection{Evaluation of Antidiabetic properties}

Evaluation of antidiabetic properties was conducted with analyzed the decreasing of blood glucose level through in vivo experiment used 20 wistar rats Rattus novergicus, divided into 5 groups (each group consist of 4 rats) then the rats were adapted for a week. During adaptation phase the rats were fed (standard AIN-93M) and feed through ad libitum drinking. To generate a hyperglicemic state (diabetic), the rats were induced by alloxan 80 $\mathrm{mg} / \mathrm{kg}$ body weight that dilluted in distilled water aquades. Each rat was injected by intraperitoneal injection as many as $2 \mathrm{ml} / 200 \mathrm{~g}$ body weight. Diabetic state will be obtained if the blood glucose level of the rats reach $>200$ $\mathrm{mg} / \mathrm{dL}$, this evaluation results were noted as the result in week-0. For each group then were divided into several condition:

$\mathrm{K} 1$ : The control-normal, were given fed standard AIN-93M

K2: Diabetic, were given fed standard AIN-93M

K3: Diabetic, were given fed biscuit control

K4: Diabetic, were given fed biscuit LFF

K5: Diabetic, were given fed biscuit PFF

Monitoring of body weight and blood glucose level were conducted every week for 4 weeks long. Blood drawing of the rats was conducted through retro orbital plexus for $1 \mathrm{ml}$. Then the blood sample was centrifuged at 4000 rpm for 15 mins at room temperature. The supernatant was collected and glucose serum level was measured by glucose oxidase 
methode using spectrophotometer at $\lambda 500 \mathrm{~nm}$. After week-14, surgical procedure was conducted to collect the rats ceacum, then the ceacum was analyzed for short chain fatty acid level by using Gas Chromatography.

\subsection{Evaluation of Anticholesterol properties}

The evaluation of anticholesterol properties of biscuit was conducted by analysis of lipid profile using in vivo methods, with 20 wistar rats, divided into 5 group (each group consisted of 4 rats). These rats were adapted for a week and fed with standard AIN-93M and ad libitum of drinking. To generate hypercholesterol condition (total of cholesterol $>150 \mathrm{mg} / \mathrm{dl}$ ), the rats were fed with high cholesterol feeding in the form of pellets which contained of $50 \mathrm{~mL}$ cooking oil, 10 g egg yolks, $0.1 \%$ propylthiouracyl (PTU). This feeding was given as $15 \mathrm{~g} /$ day, high cholesterol feeding was stopped after the rats reached hypercholesterol state, then the experimental feeding was given as:

$\mathrm{K} 1$ : Control normal, were given fed standard AIN-93M

K2: Hypercholesterol, were given fed standard AIN-93M

K3: Hypercholesterol, were given fed biscuit control

K4: Hypercholesterol, were given fed biscuit LFF

K5: Hypercholesterol, were given fed biscuit PFF

Blood drawing procedure for cholesterol analysis were obtained every week for 4 weekslong. The monitoring parameters consisted of lipid profile (total of cholesterol, LDL, HDL, triglyceride).

\subsection{Data Analysis}

Data were analyzed using split plot in time design, with SPSS software version 24.0 and Benferroni test ( $\alpha=5 \%$ ).

\section{Results and discussions \\ 3.1. Antidiabetic Properties}

Antidiabetic properties were detected from the decreasing decrease blood glucose level in rats. Analysis result showed that biscuit diet to experiment rats significantly different towards serum glucose level $(p<0.05)$, Table 1 . On the first week, blood glucose level for all groups of the rats increased up to $210.46 \mathrm{mg} / \mathrm{dL}$ after injected by alloxan, except group $\mathrm{K} 1$. Blood glucose level of diabetic rats (K2) did not show significant difference and increased up to 214.2 $\mathrm{mg} / \mathrm{dL}(1.13 \%)$. This results caused by alloxan injection affected the damage of $\beta$ pancreas cell, so insulin could not be produced again and caused permanent diabetic as reported by Szkudelski (2001).

The decreasing effect of blood glucose level in group fed with control biscuit (K3) up to $33.63 \mathrm{mg} / \mathrm{dL}$ (15.79\%). Group with biscuit LFF feeding (K4) and PFF (K5) showed decreasing effect of blood glucose level up to 101.80 $\mathrm{mg} / \mathrm{dL}(48.52 \%)$ and $109.91 \mathrm{mg} / \mathrm{dL}(52.22 \%)$. This results showed that dietary fibers and bioactive compounds of mangrove fruit flour had hypoglycemic effect, which shortened transit time in the intestine, so glucose absorption could be decreased and lowered the hyperglycemic state.

The decreasing effect of blood glucose also could be caused by bioactive compounds and dietary fibers from both types of mangrove fruits which could inhibit disaccharidase activity and extended the stomach emptying time. This mechanism caused glucose absorption slow and increased insuline sensitivity in peripheral tissues, so blood glucose level decreased. Result of study from Harijono et al. (2012) showed that feeding of water soluble polysaccharide from Gembili during 28 days could lower glucose level, then feeding of fiber from fenugreek (Trigonella foenum-graecum) could lower glucose level up to $20.27 \%$ for 4 weeks (Abdelatif et al., 2012). The average of decreasing of blood glucose level between groups after 4 weeks showed in Fig. 1 
Table 1. Effect of biscuit on blood glucose levels and body weight of normal and diabetic rats

\begin{tabular}{|c|c|c|c|c|c|c|c|}
\hline \multirow{3}{*}{ Week } & \multicolumn{7}{|c|}{ Blood glucose levels (mg/dL) } \\
\hline & \multirow{2}{*}{ K1 } & \multicolumn{6}{|c|}{ Diabetic +} \\
\hline & & K2 & \multicolumn{2}{|l|}{ K3 } & \multicolumn{2}{|c|}{ K4 } & K5 \\
\hline 0 & $65.48 \pm 1.89^{\mathrm{a}}$ & $211.82 \pm 4.73^{\mathrm{a}}$ & \multicolumn{2}{|c|}{$212.87 \pm 4.37^{\mathrm{a}}$} & \multicolumn{2}{|c|}{$209.83 \pm 4.00^{\mathrm{a}}$} & $210.46 \pm 3.37^{\mathrm{a}}$ \\
\hline 1 & $66.12 \pm 1.88^{\mathrm{a}}$ & $212.31 \pm 4.49^{b}$ & \multicolumn{2}{|c|}{$199.28 \pm 5.74^{\mathrm{b}}$} & \multicolumn{2}{|c|}{$197.21 \pm 3.36^{\mathrm{b}}$} & $195.04 \pm 2.68^{b}$ \\
\hline 2 & $66.83 \pm 1.78^{\mathrm{a}}$ & $213.33 \pm 4.39^{\mathrm{b}}$ & \multicolumn{2}{|c|}{$188.33 \pm 2.01^{\mathrm{b}}$} & \multicolumn{2}{|c|}{$160.60 \pm 2.28^{b}$} & $158.76 \pm 2.06^{\mathrm{c}}$ \\
\hline 3 & $67.11 \pm 1.88^{\mathrm{a}}$ & $213.73 \pm 4.55^{\mathrm{b}}$ & \multicolumn{2}{|c|}{$185.25 \pm 2.93^{\mathrm{b}}$} & \multicolumn{2}{|c|}{$143.03 \pm 1.53^{\mathrm{d}}$} & $140.47 \pm 1.27^{\mathrm{d}}$ \\
\hline 4 & $67.71 \pm 2.22^{\mathrm{a}}$ & $214.21 \pm 2.21^{\mathrm{b}}$ & \multicolumn{2}{|c|}{$179.24 \pm 1.29^{\mathrm{b}}$} & $108 .($ & & $100.55 \pm 1.55^{\mathrm{e}}$ \\
\hline & & \multicolumn{6}{|c|}{ Body weight (g) } \\
\hline \multirow{2}{*}{ Week } & \multirow{2}{*}{ K1 } & \multicolumn{6}{|c|}{ Diabetic +} \\
\hline & & K2 & K3 & \multicolumn{2}{|c|}{ K4 } & & K5 \\
\hline 0 & $199.25 \pm 4.03^{\mathrm{a}}$ & $190.00 \pm 3.56^{\mathrm{a}}$ & $189.75 \pm 5.12^{\mathrm{b}}$ & \multicolumn{2}{|c|}{$190.75 \pm 3.50^{\mathrm{c}}$} & \multicolumn{2}{|c|}{$193.25 \pm 2.50^{\mathrm{ab}}$} \\
\hline 1 & $206.75 \pm 4.27^{\mathrm{a}}$ & $187.00 \pm 3.56^{\mathrm{b}}$ & $194.00 \pm 5.35^{\mathrm{a}}$ & \multicolumn{2}{|c|}{$193.75 \pm 3.86^{\mathrm{c}}$} & \multicolumn{2}{|c|}{$196.50 \pm 3.00^{\mathrm{b}}$} \\
\hline 2 & $215.25 \pm 4.19^{\mathrm{a}}$ & $184.25 \pm 3.59^{\mathrm{b}}$ & $199.00 \pm 5.60^{\mathrm{a}}$ & \multicolumn{2}{|c|}{$200.25 \pm 2.99^{\mathrm{b}}$} & \multicolumn{2}{|c|}{$202.75 \pm 2.63^{\mathrm{b}}$} \\
\hline 3 & $223.25 \pm 4.99^{\mathrm{a}}$ & $182.00 \pm 3.37^{\mathrm{b}}$ & $205.75 \pm 5.56^{\mathrm{a}}$ & \multicolumn{2}{|c|}{$206.25 \pm 4.03^{b}$} & \multicolumn{2}{|c|}{$209.25 \pm 3.30^{\mathrm{a}}$} \\
\hline 4 & $230.75 \pm 3.77^{\mathrm{a}}$ & $178.00 \pm 3.16^{\mathrm{b}}$ & $211.50 \pm 4.43^{\mathrm{a}}$ & \multicolumn{2}{|c|}{$213.00 \pm 3.16^{\mathrm{a}}$} & \multicolumn{2}{|c|}{$214.75 \pm 3.50^{\mathrm{a}}$} \\
\hline
\end{tabular}

*Different code indicated the differences in one column

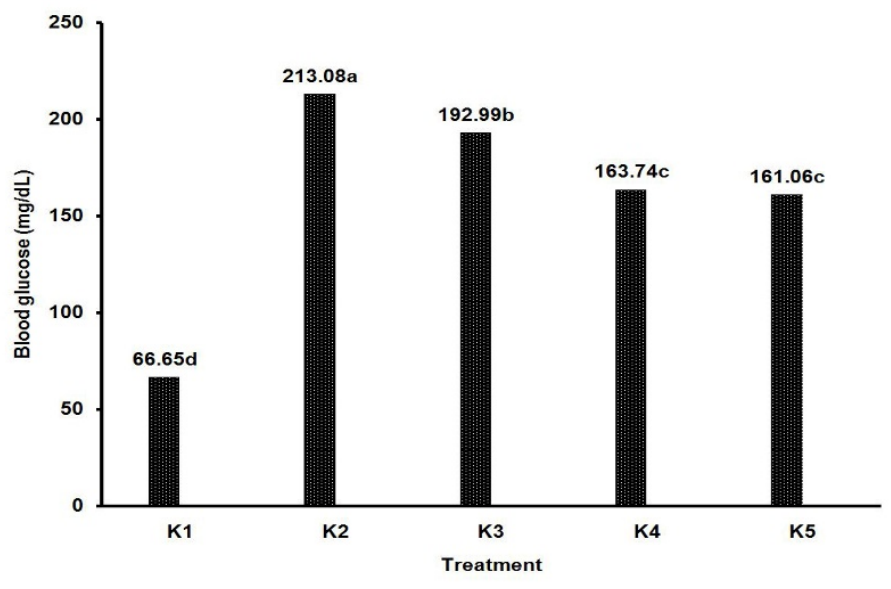

Figure 1. Changes of blood glucose of rats during 4 weeks feeding biscuit in diet

The decreasing of blood glucose level of group fed with biscuit control up to 20.09 $\mathrm{mg} / \mathrm{dL}(9.43 \%)$ compared to diabetic group fed with standard AIN 93-M (K2). Group fed with biscuit LFF (K4) showed decreasing effect up to $49.34 \mathrm{mg} / \mathrm{dL}(21.16 \%)$, and group fed with biscuit PFF (K5) showed decreasing effect up to $52.02 \mathrm{mg} / \mathrm{dL}(24.41 \%)$. The decreasing effect on this study was lower than study reported by Morada et al. (2011) showed that feeding of extract of Sonneratia alba could lower glucose level up to $66.9 \%$, while giving of fibers $50-150 \mathrm{mg} / \mathrm{kg}$ during 8 weeks could decrease glucose level up to $16-61 \%$, also 
pressed the glucose level elevation, extended the stomach emptying time and glucose difusion in the intestine (Moharib \& El-Batran, 2008).

The decreasing of glucose level was assumed also caused by polifenol, flavonoid, saponin, and tannin compounds in mangrove fruit flour. Some researchers reported that bioactive compounds like saponin, flavonoid, triterpenoid, tannin, were known to lower glucose level (Yin et al., 2004; Chandrika et al., 2006; Smith \& Adanlawo, 2014; Koneri et al.,2014; El- Barky et al., 2017).

\subsection{The Rats Body Weight}

The alteration of the rats body weight on group K2 (diabetic) decreased up to $6.32 \%$, Table 1 . This was caused by $\beta$ pancreas cell was damaged due to induction of alloxan, so insulin could not be produced and glucose could not enter cell tissues. Because of this mechanism, glycogenesis process was disrupted both in the muscle and liver, so glycogen production also decreased and followed by decrease of muscle mass that affect body weight. Sousa et al. (2015) reported that glycogen in the liver will increase as well as glycogenesis process increase.

The increase of body weight of group fed with biscuit control (K3) was less higher than biscuit LFF (K4) feeding amount $11.66 \%$. This was caused by sour taste on biscuit PFF which can affect the appetite, then body weight of group fed with biscuit PFF (K5) increased up to $11.13 \%$. The increase of body weight showed that bioactive compound and dietary fiber of mangrove fruit flour could enhance peripheral insulin sensitivity, so glucose could be absorbed into celland body weight increased. Dietary fiber could repair pancreatic function to produce insulin (Lattimer \& Haub, 2010), so cell could acquire enough energy to store glucose in the muscle and the rats body weight would increase (Weyer et al., 2001), the other hand diabetic caused protein glycation and affect body weight (Yin et al., 2004 ).

\subsection{Short Chain Fatty Acid (SCFA)}

The average level of SCFA acetic acid in the cecum of rats after 4 weeks was 20.25 to $24.90 \mathrm{mMol} / \mathrm{L}$, butiric acid from 29.36 to 38.70 $\mathrm{mMol} / \mathrm{L}$, and propionic acid from 2.64 to 4.51 $\mathrm{mMol} / \mathrm{L}$. The result of analysis showed that feeding of biscuit from mangrove fruit flour was not significantly different towards acetic acid and butiric acid level ( $>0.05)$, but significantly different $(\mathrm{p}<0.05) \quad$ towards propionic acid level.

Fig. 2 showed that group of control (normal rats) and group of diabetic rats with feeding standard AIN 93M had the same profile, this was due to feeding of standard contained of fiber from $\mathrm{CMC}$ which could be degraded into SCFA. The highest level of propionic acid and butiric acid were found at group fed by biscuit PFF, LFF, and control. SCFA as the fermentation product will be absorbed in the intestine and transported into liver through enterohepatic circulation. It was a system which connected a tube between liver and intestine to help digestive process and used for metabolic substance by liver (Koh et al., 2016).

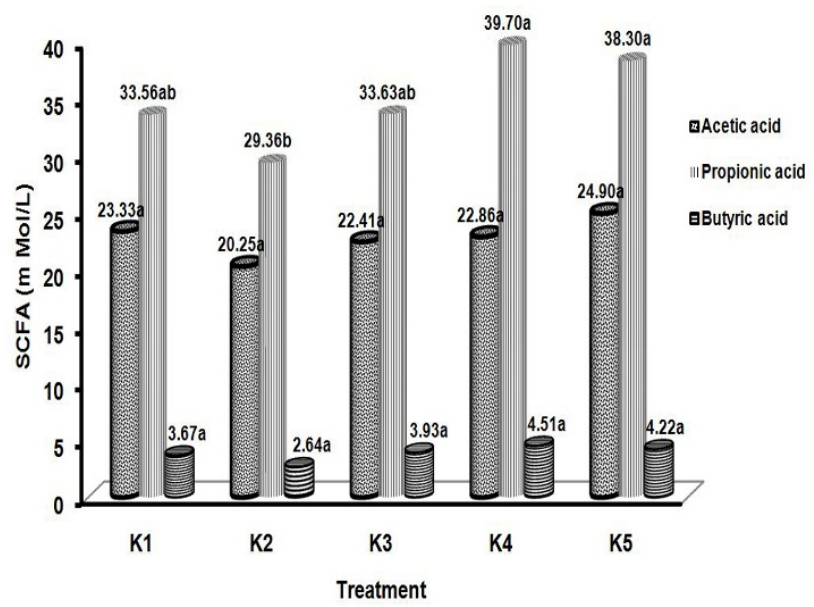

Figure 2. Profile of SCFA

The increase of SCFA production gave benefits in order to lower the glucose production by liver (Harijono, 2012). SCFA was metabolized at three parts of the body i.e., at colonic epithelial cell which used butiric as main substrate to maintain energy production; at liver cell which metabolized butiric residue 
and propionic to be utilized in gluconeogenesis; and muscle cell which conducted acetic residue oxidation to produce energy. Soluble dietary fiber like pectine and guar gum generally fastly fermented in the colon (Topping \& Clifton,
2001; Henningsson et al., 2002), but insoluble dietary fiber like cellulose, hemicellulose, and lignin only have small effect on postprandial glucose (Dikeman \& Fahey, 2006).

Table 2. Effect of biscuit on total cholesterol, LDL-C, levels of normal and hypercholesterol of rats

\begin{tabular}{|c|c|c|c|c|c|}
\hline \multirow{2}{*}{ Week } & \multicolumn{5}{|c|}{ Total Cholesterol levels (mg/dL) } \\
\cline { 2 - 6 } & \multirow{2}{*}{ K1 } & \multicolumn{4}{c|}{ Hypercholesterol + } \\
\cline { 3 - 6 } & & K2 & K3 & K4 & K5 \\
\hline 0 & $85.43 \pm 1.71^{\mathrm{a}}$ & $184.77 \pm 4.52^{\mathrm{a}}$ & $182.45 \pm 3.69^{\mathrm{a}}$ & $182.45 \pm 2.06^{\mathrm{a}}$ & $181.29 \pm 1.47^{\mathrm{a}}$ \\
\hline 1 & $87.42 \pm 2.00^{\mathrm{b}}$ & $186.24 \pm 4.66^{\mathrm{a}}$ & $159.73 \pm 2.79^{\mathrm{b}}$ & $153.69 \pm 1.45^{\mathrm{b}}$ & $146.31 \pm 1.97^{\mathrm{b}}$ \\
\hline 2 & $87.77 \pm 2.18^{\mathrm{b}}$ & $186.50 \pm 4.64^{\mathrm{a}}$ & $151.28 \pm 1.92^{\mathrm{b}}$ & $139.24 \pm 3.18^{\mathrm{b}}$ & $129.57 \pm 3.07^{\mathrm{c}}$ \\
\hline 3 & $88.91 \pm 2.19^{\mathrm{b}}$ & $187.25 \pm 4.73^{\mathrm{a}}$ & $132.95 \pm 1.82^{\mathrm{c}}$ & $118.05 \pm 3.48^{\mathrm{c}}$ & $110.43 \pm 2.19^{\mathrm{d}}$ \\
\hline 4 & $89.60 \pm 2.23^{\mathrm{b}}$ & $188.09 \pm 4.73^{\mathrm{a}}$ & $127.52 \pm 1.65^{\mathrm{d}}$ & $112.25 \pm 4.47^{\mathrm{d}}$ & $104.87 \pm 2.53^{\mathrm{e}}$ \\
\hline \multirow{2}{*}{ Week } & \multirow{2}{*}{$\mathbf{K 1}$} & $\mathbf{L D L}-\mathbf{c} \mathbf{( m g / d L )}$ & $\mathbf{H y p e r c h o l e s t e r o l +}$ & \\
\hline & & $\mathbf{K 2}$ & $\mathbf{K 3}$ & $\mathbf{K 4}$ & $\mathbf{K 5}$ \\
\hline 0 & $34.61 \pm 1.60^{\mathrm{a}}$ & $75.95 \pm 1.73^{\mathrm{a}}$ & $77.16 \pm 2.08^{\mathrm{a}}$ & $76.13 \pm 1.27^{\mathrm{a}}$ & $74.91 \pm 2.07^{\mathrm{a}}$ \\
\hline 1 & $35.11 \pm 1.36^{\mathrm{a}}$ & $76.77 \pm 1.57^{\mathrm{a}}$ & $68.44 \pm 2.74^{\mathrm{a}}$ & $63.83 \pm 2.09^{\mathrm{b}}$ & $54.97 \pm 1.88^{\mathrm{b}}$ \\
\hline 2 & $35.86 \pm 1.26^{\mathrm{a}}$ & $75.52 \pm 4.52^{\mathrm{a}}$ & $60.17 \pm 2.28^{\mathrm{a}}$ & $56.72 \pm 1.73^{\mathrm{b}}$ & $50.86 \pm 1.89^{\mathrm{c}}$ \\
\hline 3 & $37.20 \pm 2.14^{\mathrm{a}}$ & $78.20 \pm 3.87^{\mathrm{a}}$ & $55.88 \pm 2.90^{\mathrm{b}}$ & $44.64 \pm 2.15^{\mathrm{c}}$ & $39.97 \pm 1.53^{\mathrm{d}}$ \\
\hline 4 & $37.99 \pm 2.11^{\mathrm{a}}$ & $79.03 \pm 4.11^{\mathrm{a}}$ & $53.23 \pm 2.77^{\mathrm{c}}$ & $42.29 \pm 1.55^{\mathrm{c}}$ & $37.10 \pm 1.59^{\mathrm{e}}$ \\
\hline
\end{tabular}

*Different code indicated the differences in one column

\subsection{Anticholesterol Properties}

Anticholesterol properties of biscuit was evaluated from lipid profile which consisted of total cholesterol, LDL, HDL, and triglyceride. The total cholesterol level of rats in hypercholesterolemic up to $184.77 \mathrm{mg} / \mathrm{dL}$ $(53.12 \%)$ higher than the initial condition. The total cholesterol level of group K1 and K2 during 4 weeks did not significantly increase and tend to be stable (Table 2). Decreasing effect of total cholesterol in group $\mathrm{K} 3$ up to $54.93 \mathrm{mg} / \mathrm{dL}(30.10 \%)$, while the group K4 and K5 decreased up to $70.20 \mathrm{mg} / \mathrm{dL}(38.47 \%)$ and $76.42 \mathrm{mg} / \mathrm{dL}(42.15 \%)$. The lowest total cholesterol level was shown in group K5, the decreasing effect in this group is lower than previous study by giving orange peel extract $125 \mathrm{mg} / \mathrm{kg}$ body weight could lower total cholesterol level up to $54.77 \mathrm{mg} / \mathrm{dL}$ (Muhtadi et al., 2015).

But this result was lower than giving of soluble fiber $\beta$-glucan $3.30 \%$ which could lower total cholesterol more than $33.00 \%$ (Dikeman \& Fahey, 2006). The diet which consists of much dietary fiber causes extending absorption of food and carbohydrate in the intestine, so postprandial glucose level will decrease. This condition decreases insulin secretion that will affect inhibition of HMG Co-A reductase, so the synthesis of cholesterol will also decrease (Daubioul et al., 2002).

The other factors which also play role in decreasing cholesterol were saponin, flavonoid, tannin instead of dietary fiber contained in mangrove fruit flour. Three factors could bind 
bile acid in the intestine. Bile acid was produced from cholesterol and absorbed again by the intestine, inhibition of reabsorption of bile acid and throwing through feces could decrease cholesterol level in blood (Dasofunjo et al., 2012).

The presence of phenol in mangrove fruit flour also played role to lower the total cholesterol. Phenol compound has proven could lower hypercholesterolemia (Bok et al., 1999; Rehrah et al., 2007) because phenol was able to inhibit modification of LDL oxidation that could cause atherosclerosis. The function of antioxidant promoted cholesterol eflux which mediated by HDL. Capacity of cholesterol eflux increase as presence of flowing HDL, where this condition depended on the length and saturation of fatty acid in HDL (Arora et al.,2000). The presence of phenol compound in mangrove fruit flour was able to lower total cholesterol. Phenol compound has proven could lower hypercholesterolemia The previous study showed that, when HDL was oxidized, HDL would loose its unsaturated fatty acids, so the lowering capacity of free cholesterol would also decrease. This had relation with decrease of HDL flow rate (Shehata \& Soltan, 2012). The alteration of decreasing effect of cholesterol during 4 weeks between groups shown in Fig. 3.

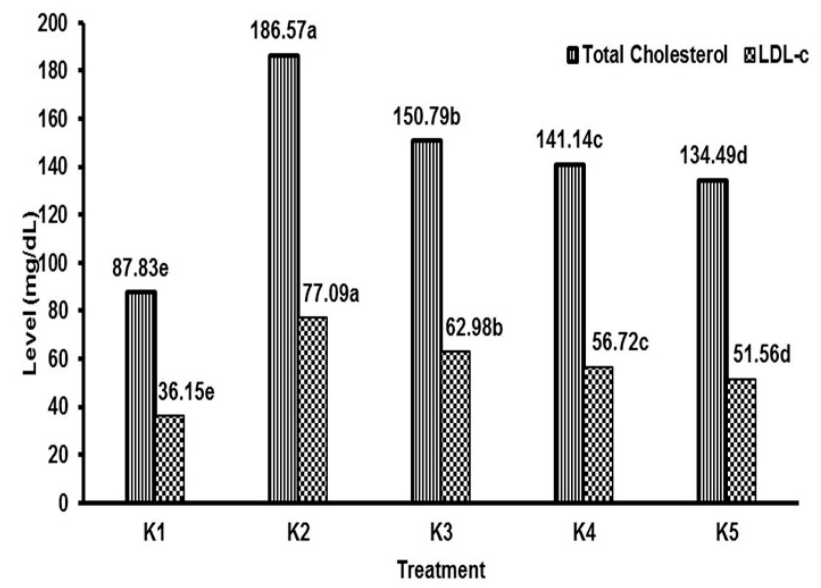

Figure 3. Changes of cholesterol total and LDL-c of rats during 4 weeks feeding biscuit in diet
Fig. 3 showed that group fed with biscuit control (K3) had decreasing effect on cholesterol up to $35.80 \mathrm{mg} / \mathrm{dL}(19.18 \%)$ rather than group K2 (negative control), while group fed with biscuit LFF (K4) and biscuit PFF (K5) had decreasing effect $45.43 \mathrm{mg} / \mathrm{dL}(24.35 \%)$ and $52.08 \mathrm{mg} / \mathrm{dL}(27.91 \%)$.

This decreasing effect was assumed that dietary fiber and bioactive compounds saponin, flavonoid, tannin in mangrove fruit flour had a role in decreasing cholesterol. Hasanah et al. (2016) proved that tannins could inhibit HMG Co-A reductase and acyl-Coenzym A Cholesterol acyltransferase (ACAT) which was enzyme for cholesterol synthesis, absorption, and its release to blood stream.

\subsection{LDL-c}

The average of LDL cholesterol (LDL-c) for every week shown in Table 2 and Fig. 3. The LDL-c in normal and hypercholesterolemia rats were given fed standard AIN 93-M during 4 weeks did not show significant difference, but the rats were given fed biscuit control (K3), biscuit LFF (K4), and biscuit PFF (K5) could lower LDL-c level significantly for each group $23.93 \mathrm{mg} / \mathrm{dL}(31.01 \%) ; 33.84$ (44.45\%) and $37.81 \mathrm{mg} / \mathrm{dL}(50.47 \%)$. This showed that soluble dietary fiber in mangrove fruit flour was able to lower LDL-c level, while insoluble dietary fiber (cellulose. hemocellulose, lignin) was not able to lower LDL-c level. The previous study stated that soluble dietary fiber of orange peel was able to lower LDL-c up to $53.47 \%$ [33]. Furthermore El- Khoury et al. (2012) reported that feeding of soluble dietary fiber from $\beta$-glucan amount $10 \mathrm{~g}$ /day during 5 weeks could lower LDL-c up to $14.30 \mathrm{mg} / \mathrm{dL}$. All types of soluble dietary fiber such as psyllium, pectin, and guar gum had ability in decreasing LDL-c level (Brown et al., 1999).

The mechanism of decreasing LDL-c level by dietary fiber is that dietary fiber can alter absorption and metabolism of bile acid; dietary fiber can modify absorption and metabolism of lipid; short chain fatty acid procuded in fermentation of dietary fiber can affect 
metabolism of cholesterol and lipoprotein; and dietary fiber can alter insulin or other homones concentration and tissue sensitivity to hormone (Anderson et al., 1999).

Soluble dietary fiber also extend stomach emptying process and bind bile acid, so bile acid level decrease. In result, the body naturally produce bile acid from cholesterol in the blood stream. The absorption of blood cholesterol cause VLDL level which was procuded will be in small amount. Because of LDL was synthetized from VLDL, so decreasing of VLDL also lower LDL-c level in blood (Eze et al., 2014). According to Then et al. (2009) decreasing of cholesterol would lower remnant chilomicron. so the conversion of VLDL to LDL decreased.

\subsection{HDL-c}

The average level of HDL cholesterol (HDL-c) every week shown in Table 3. This table showed that HDL-c level in group of normal rats, and hypercholestrolemia rats during 4 weeks did not significant differences $(\mathrm{p}>0.05)$. But group fed with biscuit control (K3) the HDL-c level increased up to 20.51 $\mathrm{mg} / \mathrm{dL}(45.07 \%)$, group fed with LFF (K4) up to $32.51 \mathrm{mg} / \mathrm{dL}(56.36 \%)$ and group fed with PFF (K5) up to $33.35 \mathrm{mg} / \mathrm{dL}(56.17 \%)$. The increase of HDL was assumed that presence of dietary fiber and bioactive compound in mangrove fruit flour such as flavonoids, tannins, saponins, and phenol gave significant effect to increase HDL-c.

Table 3. Effect of biscuit on HDL-C and triglyceride levels of normal and hypercholesterol of rats

\begin{tabular}{|c|c|c|c|c|c|}
\hline \multirow{3}{*}{ Week } & \multicolumn{5}{|c|}{ Total Cholesterol levels (mg/dL) } \\
\hline & \multirow{2}{*}{ K1 } & \multicolumn{4}{|c|}{ Hypercholesterol + } \\
\hline & & K2 & K3 & K4 & $\mathbf{K 5}$ \\
\hline 0 & $85.43 \pm 1.71^{\mathrm{a}}$ & $184.77 \pm 4.52^{\mathrm{a}}$ & $182.45 \pm 3.69^{\mathrm{a}}$ & $182.45 \pm 2.06^{\mathrm{a}}$ & $181.29 \pm 1.47^{\mathrm{a}}$ \\
\hline 1 & $87.42 \pm 2.00^{\mathrm{b}}$ & $186.24 \pm 4.66^{\mathrm{a}}$ & $159.73 \pm 2.79^{b}$ & $153.69 \pm 1.45^{\mathrm{b}}$ & $146.31 \pm 1.97^{\mathrm{b}}$ \\
\hline 2 & $87.77 \pm 2.18^{b}$ & $186.50 \pm 4.64^{\mathrm{a}}$ & $151.28 \pm 1.92^{\mathrm{b}}$ & $139.24 \pm 3.18^{b}$ & $129.57 \pm 3.07^{\mathrm{c}}$ \\
\hline 3 & $88.91 \pm 2.19^{b}$ & $187.25 \pm 4.73^{\mathrm{a}}$ & $132.95 \pm 1.82^{\mathrm{c}}$ & $118.05 \pm 3.48^{\mathrm{c}}$ & $110.43 \pm 2.19^{d}$ \\
\hline 4 & $89.60 \pm 2.23^{b}$ & $188.09 \pm 4.73^{\mathrm{a}}$ & $127.52 \pm 1.65^{\mathrm{d}}$ & $112.25 \pm 4.47^{\mathrm{d}}$ & $104.87 \pm 2.53^{\mathrm{e}}$ \\
\hline \multicolumn{6}{|c|}{ LDL -c (mg/dL) } \\
\hline \multirow{2}{*}{ Week } & \multirow{2}{*}{ K1 } & \multicolumn{4}{|c|}{ Hypercholesterol+ } \\
\hline & & K2 & K3 & K4 & K5 \\
\hline 0 & $34.61 \pm 1.60^{\mathrm{a}}$ & $75.95 \pm 1.73^{\mathrm{a}}$ & $77.16 \pm 2.08^{\mathrm{a}}$ & $76.13 \pm 1.27^{\mathrm{a}}$ & $74.91 \pm 2.07^{\mathrm{a}}$ \\
\hline 1 & $35.11 \pm 1.36^{\mathrm{a}}$ & $76.77 \pm 1.57^{\mathrm{a}}$ & $68.44 \pm 2.74^{\mathrm{a}}$ & $63.83 \pm 2.09^{\mathrm{b}}$ & $54.97 \pm 1.88^{\mathrm{b}}$ \\
\hline 2 & $35.86 \pm 1.26^{\mathrm{a}}$ & $75.52 \pm 4.52^{\mathrm{a}}$ & $60.17 \pm 2.28^{\mathrm{a}}$ & $56.72 \pm 1.73^{b}$ & $50.86 \pm 1.89^{c}$ \\
\hline 3 & $37.20 \pm 2.14^{\mathrm{a}}$ & $78.20 \pm 3.87^{\mathrm{a}}$ & $55.88 \pm 2.90^{\mathrm{b}}$ & $44.64 \pm 2.15^{\mathrm{c}}$ & $39.97 \pm 1.53^{\mathrm{d}}$ \\
\hline 4 & $37.99 \pm 2.11^{\mathrm{a}}$ & $79.03 \pm 4.11^{\mathrm{a}}$ & $53.23 \pm 2.77^{\mathrm{c}}$ & $42.29 \pm 1.55^{\mathrm{c}}$ & $37.10 \pm 1.59^{\mathrm{e}}$ \\
\hline
\end{tabular}

*Different code indicated the differences in one column

The increase of HDL-c level might be caused by increase of apolipoprotein A with undefined mechanism. Apolipoprotein (A) is one of protein molecule that support forming of HDL-c particles (Eze et al., 2014). In Fig. 4 showed that the increase of HDL-c in group fed with biscuit control (K3) up to $10.69 \mathrm{mg} / \mathrm{dL}$ compared with group of hypercholesterolemic rats fed with standar AIN-93M. while group fed with biscuit LFF (K4) and grup fed with 
biscuit PFF (K5) for each group increased up to $18.52 \mathrm{mg} / \mathrm{dL}$ and $21.84 \mathrm{mg} / \mathrm{dL}$.

\subsection{Triglyceride}

The average of triglyceride level in group of normal rats. hypercholesterolemic rats, and group fed with biscuit control did not show significant differences, but group feeding of biscuit LFF (K4) and PFF (K5) could lower triglyceride significantly every week, Table 3. The decreasing of triglyceride of group K4 and $\mathrm{K} 5$ for each up to $27.93 \mathrm{mg} / \mathrm{dL}(21.89 \%)$; and $42.02 \mathrm{mg} / \mathrm{dL}(32.35 \%)$.

The mechanism of decreasing triglyceride was assumed that affected by level of soluble dietary fiber (pectin) from mangrove fruit flour and short chain fatty acid from dietary fiber fermentation in the rats colon. Pectin could inhibit absorption lipid in the intestine, so triglyceride and cholesterol in blood would decrease. In the gastrointestinal tract, pectin binds bile acid and excretes it together with feces. Dietary fiber also binds bile acid so it can not re-enter to enterohepatic cycle and increases bile acid excretion in fecal with various mechanism such as bile acid binding, gel forming, and micelle form binding (Dhingra et al.,2012). If the excretion of bile acid increases, cholesterol and triglyceride absorption will be disrupted and triglyceride serum level will decrease.

Fig. 4 showed that decreasing of triglyceride after consuming biscuit from mangrove fruit flour during 4 weeks could not reach level nearest to triglyceride from group of normal rats.

Research from Abdelbaky et al. (2009) showed that triglyceride decreased up to $48.26 \%$ and could reach triglyceride level nearest to group of control (normal). The decreasing of triglyceride by soluble dietary fiber occured inconsistently, soluble dietary fiber from barley was known could lower triglyceride level (Talati et al., 2009), while other soluble dietary fibers like psyllium, oat, and guar gum could lower total cholesterol but not followed by decreasing of triglyceride significantly (Slavin et al., 2009). In group of rats fed with biscuit control, triglyceride lowered up to $11.29 \mathrm{mg} / \mathrm{dL}$ $(8.66 \%)$ compared with group of hypercholesterolemic rats (K2), while group fed with biscuit LFF (K4) and PFF (K5), for each group was $19.97 \mathrm{mg} / \mathrm{dL}(15.28 \%)$ and $25.98 \mathrm{mg} / \mathrm{dL}$ (19.93\%).

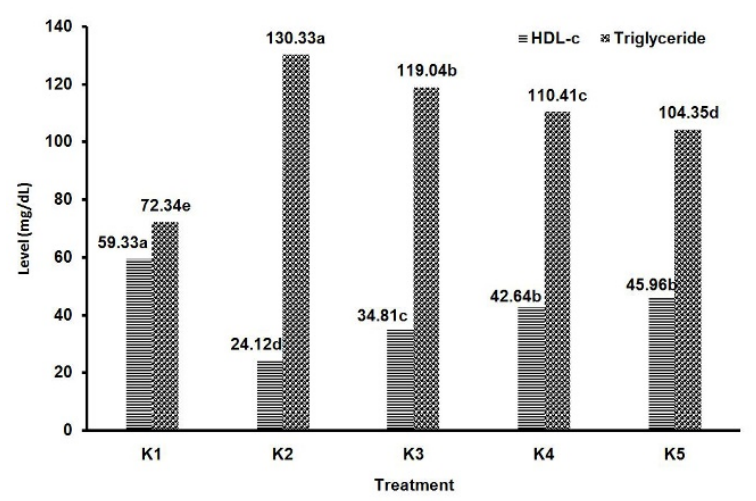

Figure 4. Changes of LDL-c and triglyceride of rats during 4 weeks feeding biscuit in diet

\section{Conclusions}

The mangrove fruit flour-substituted biscuits has antidiabetic properties which able to decrease blood glucose level in rats up to $101.80 \mathrm{mg} / \mathrm{dL}$ for biscuit LFF and 109.91 $\mathrm{mg} / \mathrm{dL}$ for biscuit PFF. These biscuits also had anticholesterol properties which able to lower total cholesterol up to $70.20 \mathrm{mg} / \mathrm{dL}$ for biscuit LFF and $76.42 \mathrm{mg} / \mathrm{dL}$ for biscuit PFF. LDL-c lowered up to $33.84 \mathrm{mg} / \mathrm{dL}$ for biscuit LFF and $37.81 \mathrm{mg} / \mathrm{dL}$ for biscuit PFF. While HDL-c increased up to $32.51 \mathrm{mg} / \mathrm{dL}$ for biscuit LFF and $33.35 \mathrm{mg} / \mathrm{dL}$ for biscuit PFF. Triglyceride lowered up to $27.93 \mathrm{mg} / \mathrm{dL}$ and $42.02 \mathrm{mg} / \mathrm{dL}$ for each biscuit LFF and biscuit PFF. The SCFA in cecum of rats after 4 weeks as followed $20.25 \mathrm{mMol} / \mathrm{L}$ to $24.90 \mathrm{mMol} / \mathrm{L}$ for acetic acid and $29.36 \mathrm{mMol} / \mathrm{L}$ to $39.70 \mathrm{mMol} / \mathrm{L}$ for butiric acid, $2.64 \mathrm{mMol} / \mathrm{L}$ to $4.51 \mathrm{mMol} / \mathrm{L}$ for propionic acid.

\section{References}

Abdelatif, A. M., Ibrahim, M. Y., Mahmoud, A. S., (2012). Antidiabetic effects of fenugreek (Trigonella foenum-graecum) seeds in the domestic rabbit (Oryctolagus 
cuniculus). Research Journal of Medicinal Plant, 6(6), 449-455.

Abdelbaky, M. S., Elmehiry, H. F., Ali, N. K. M. (2009). Effect of some citrus peels on hypercholesterolemic rats. Proceedings of the $1^{\text {st }}$ International and $4^{\text {th }}$ Arab Annual Scientific Conference on: Academic Acreditation for Higher Spesific Education Institutions and Programs in Egypt and Arab World Reality and Expectation, 2009, 1627-1639.

Anderson, J. W., Deakins, D. A., Bridges, S. R. (1999). Soluble Fiber, Hypocholesterolemic Effects and Proposed Mechanism. In D. Kritchevsky, C. Bonfield, J. W. Anderson (Ed), Dieatry Fiber: Chemistry, Physiology, and Health Effects. (pp. 339-358), New York: Plenum Press.

Arora, A., Byrem, T. M., Nair, M. G., Strasburg, G. M. (2000). Modulation of liposomal membrane fluidity by flavonoids and isoflavonoids. Archives of biochemistry and biophysics, 373(1), 102-109.

Bok, S. H., Lee, S. H., Park, Y. B., Bae, K. H., Son, K. H., Jeong, T. S., Choi, M. S. (1999). Plasma and hepatic cholesterol and hepatic activities of 3-Hydroxy-3-MethylGlutaryl-CoA reductase and acyl coA: cholesterol transferase are lower in rats fed citrus peel extract or a mixture of citrus bioflavonoids. The Journal of nutrition, 129(6), 1182-1185, 1999.

Brown, L., Rosner, B., W. Willett, W., Sacks, F. M. (1999). Cholesterol-lowering effects of dietary fiber: a meta-analysis. The American journal of clinical nutrition, 69(1), 30-42.

Chandrika, U. G., Wedage, W. S., Wickramasinghe, S. M. D. N., Fernando, W. S. (2006) Hypoglycaemic action of the flavonoid fraction of Artocarpus heterophyllus leaf. African Journal of Traditional, Complementary and Alternative Medicines, 3(2), 42-50.

Dasofunjo, K., Nwodo, F. O. C., Ipav, S. S., $\mathrm{Ngu}, \mathrm{T}$. A. (2012). The effect of ethanolic leaf extract of Piliostigma thonningii on serum lipid profile of male wistar albino rats. Journal of Natural Product and Plant Resources, 2 (6), 665-669.

Daubioul, C., Rousseau, N., Demeure, R., Gallez, B., Taper, H., Declerck, B., N. Delzenne. (2002). Dietary fructans, but not cellulose, decrease triglyceride accumulation in the liver of obese Zucker $\mathrm{fa} / \mathrm{fa}$ rats. The Journal of nutrition, 132(5), 967-973, 2002.

Dhingra, D., Michael, M., Rajput, H., Patil, R. T. (2012) Dietary fiber in foods: a review. Journal of food science and technology, 49(3), 255-266.

Dikeman, C. L., Fahey, G. C. (2006). Viscosity as related to dietary fiber: a review. Critical reviews in food science and nutrition, 46(8), 649-663.

El- Barky, A. R., Hussein, S. A., Alm-Eldeen, A. A., Hafez, Y. A., Mohamed, T. M. (2017). Saponins and their potential role in diabetes mellitus. Review Diabetes Management, 7(1), 148-158.

El- Khoury, D., Cuda, C., Luvohyy, B. L., Anderson, G. H. (2012). Beta glucan: health benefits in obesity and metabolic syndrome. Journal of Nutrition and Metabolism, 2012, 1-28.

El- Sharnouby, G. A., Aleid, S. M., Al-Otaibi, M. M. (2012). Nutritional Quality of Biscuit Supplemented with Wheat Bran and Date Palm Fruits (Phoenix dactylifera L.). Food and Nutrition Science, 3(3), 322-328.

Eze, O. F., Ani, J. C., Obasi, N. E. (2014). Dietary fibre potentials of some selected flours and their effect on blood glucose and serum cholesterol reduction. European Journal of Food Science and Technology, 2(2), 1-12.

Gaziano, T. A. (2007). Recuing the growing burden of cardiovascular disease in the developing world. Health Affairs (Millwood), 26(1), 13-24.

Harijono, Estiasih, T., Suharharum, W. B., Suwita, I. K. (2012). Effect of hypoglycemic water-slouble polysaccharides from Dioscorea esculanta. Journal of Technology and Food Industry, 23,1-8. 
Hasanah, Q., Hasim, Faridah, D. N., Andrianto, D. (2016). Inhibition activity of HMG-CoA reductase by rice brain extract and its fractions as anticholesterolemia in vitro study. Der Pharma Chemica, 8(23), 1-5.

Henningsson, A. M., Björck, I. M., Nyman, E. M. (2002). Combinations of indigestible carbohydrates affect short-chain fatty acid formation in the hindgut of rats. The Journal of nutrition, 132(10), 3098-3104.

Jariyah, J., Widjanarko, S. B., Yunianta, Estiasih T., Sopade P. A. (2014). Pasting properties of mangrove fruit flour and starches mixtures. International Food Research Journal, 21(6), 2161-2167.

Jariyah, J., Widjanarko, S. B., Yunianta, Estiasih, T. (2015). Phytochemical and acute toxicity studies of ethanol extract from Pedada (Sonneratia caseolaris) fruit flour (PFF). International Journal on Advanced Science, Engineering and Information Technology, 5(2), 95-98.

Jariyah, J., Widjanarko, S. B., Yunianta, Estiasih, T. (2016). Quality evaluation of Wheat-Pedada Fruit Flour (PFF) biscuit with different emulsifiers. Agriculture and Agricultural Science Procedia, 9(2016),518 $-524$.

Harijono, Estiasih, T., Sunarharum, W. B., Hartono, M. D. (2013). Hypoglecemic effect of biscuits containing water-soluble polysaccharides from wild yam (Dioscorea hispida Dennts) or lesser yam (Dioscorea esculanta) tubers and alginate. International Food Research Journal, 20(5), 2279-2285.

Koh, A., de Vadder, F., Kovatcheva-Datchary, P., Bäckhed, F. (2016). From dietary fiber to host physiology: short-chain fatty acids as key bacterial metabolites. Cell,165(6), 1332-1345.

Koneri, R. B., Sammadar, S., Ramalah. (2014). Antidiabetic activity of a triterpenoid saponin isolated from Momordica cymbalaria Fenzl. Indian journal of experimental biology, 52(1),46-52.

Lattimer, J. M., Haub, M. D. (2010). Effects of dietary fiber and its components on metabolic health. Nutrients, 2(12), 12661289.

Moharib, S. A., El-Batran. (2008). Hypoglycemic effect of diatery fibre in diabetic rats. Research Journal of Agriculture and Biological Sciences, 4(5), 455-461.

Morada, N. J., Metillo, E. G., Uy, M. M., Oclarit, J. M. (2011). Anti-diabetic polysaccharide from mangrove plant, Sonneratia alba Sm. International Conference on Asia Agriculture and Animal, 1(2011), 197-200.

Muhtadi, Haryoto, Azizah, T., Suhendi, A., Yen K. H. (2015). Antidiabetic and anti hypercholesterolemic activities of Citrus sinensis peel : in vivo study. National Journal of Physiology, Pharmacy and Pharmacology, 5(5), 382-385.

Rehrah, D., Ahmedna, M., Yu, J., Goktepe, I., Hurley, S., Anner, T., Rao, A. P. (2007) Enhanced cholesterol and triglyceride lowering effect of West African green tea. Journal of the Science of Food and Agriculture, 87(7), 1323-1329.

Shehata, M. M. S. M., Soltan, S. S. A. (2012). The effects of purslane and celery on hypercholesterolemic mice. World Journal of Dairy and Food Sciences, 7 (2), 212221.

Sindhuja, A., Sudha, M. L., Rahim A. (2005). Effect of incorporation of amaranth flour on the quality of cookies. European Food Research and Technology, 221(2005), 597601.

Slavin, J. L., Savarino, V., Paredes-Diaz, A., Fotopoulos, G. (2009). A review of the role of soluble fiber in health with specific reference to wheat dextrin. The Journal of international medical research, 37(1),1-17.

Smith, Y. R. A., Adanlawo, I. G. (2014). Hypoglycaemic effect of saponin from the root of Garcinia kola (Bitter Kola) on alloxan-induced diabetic rats. Journal of Drug Delivery \& Therapeutics, 2(6), 9-12.

Sousa, R. V. R. B., Guedes, M. I. F., Marques, M. M. M., Viana, D. A., da Silva, I. N. G., Rodrigues, P. A. S., Vieira, I. G. P. (2015). 
Hypogkycemic effect of new pectin isolated from Passiflora glandulosa Cav in alloxan-induced diabetic mice, World Journal of Pharmacy and Pharmaceutical Sciences, 4(1),1571 -1586.

Szkudelski, T. (2001). The mechanism of aloxan and streptozotocin action in $\beta$ cells of the rat pancreas. Physiological research / Academia Scientiarum Bohemoslovaca, 50(6), 536-328.

Talati, R., Baker, W. L., Pabilonia, M. S., White, C. M., Coleman, C. I. (2009). The effects of Barley-derived soluble fiber on serum lipids. Annals of family medicine, 7(2), 157-163.

Then, A. H., Bardosono, S., Harahap, I. P. (2009). The effect of indigestible dextrin and phytosterol on serum LDL-cholesterol level on hypercholesterolemic subjects. Medical Journal of Indonesia, 18(2), 114119.

Topping, D. L., Clifton, P. M. (2001). Shortchain fatty acids and human colonic function: roles of resistant starch and nonstarch polysaccharides. Physiological reviews, 81(3), 1031-1064.

Weyer, C., Tataranni, P. A., Bogardus, C., Pratley, R E. (2001). Insulin resistance and insulin secretory disfunction are independent predictors of worsening of glucose tolerance during each stage of type 2 diabetes development. Diabetes Care, 24(1), 89-94.

Yin, X., Zhang, Y., Wu, H., Zhu, X., Zheng, X., Jiang, S., Zhuo, H., Shen, J., Li, L., Qiu, J. (2004). Protective effects of Astragalus saponin I on early stage of diabetic nephropathy in rats. Journal of pharmacological sciences, 95(2),256-266.

\section{Acknowledgment}

This study was a part of Leading Research of Universities, researchers would say thank you for the support of research funding from Indonesian Ministry of Research, Technology, and Higher Education in 2017. 